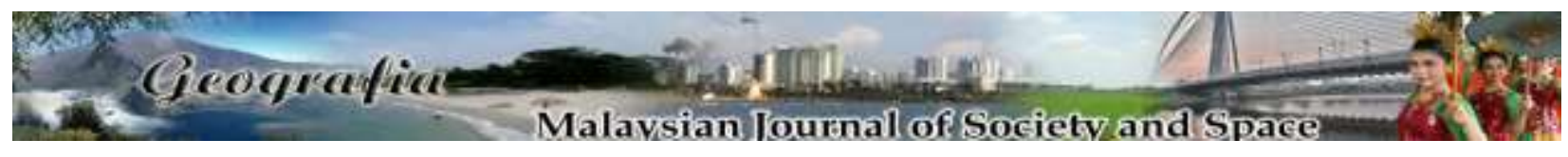

\title{
Penggunaan dan penerimaan bahan bantu mengajar multimedia terhadap keberkesanan pembelajaran Geografi
}

\author{
Hanifah Mahat ${ }^{1}$, Satryani Arshad ${ }^{1}$, Yazid Saleh $^{1}$, Kadaruddin Aiyub $^{2}$, Mohmadisa Hashim $^{1}$, Nasir Nayan $^{1}$ \\ ${ }^{1}$ Jabatan Geografi \& Alam Sekitar, Fakulti Sains Kemanusiaan, \\ Universiti Pendidikan Sultan Idris \\ ${ }^{2}$ Program Geografi, Pusat Kajian Pembangunan, Sosial dan Persekitaran, \\ Fakulti Sains Sosial dan Kemanusiaan, Universiti Kebangsaan Malaysia \\ Correspondence: Hanifah Mahat (email: hanifah.mahat@fsk.upsi.edu.my)
}

Received: 13 September 2019; Accepted: 02 January 2020; Published: 28 August 2020

\begin{abstract}
Abstrak
Kaedah pengajaran tradisional sepenuhnya dalam menyampaikan isi kandungan mata pelajaran Geografi akan menyukarkan kefahaman dan seterusnya memberi kesan terhadap minat pelajar dalam mata pelajaran Geografi. Atas asas permasalahan ini, kajian ini bertujuan meneliti penggunaan bahan bantu mengajar (BBM) multimedia dalam pembelajaran Geografi Tingkatan Enam di Malaysia. Penelitian melibatkan tiga pemboleh ubah kajian iaitu penggunaan elemen BBM multimedia, penerimaan pelajar terhadap reka bentuk BBM multimedia, dan keberkesanan penggunaan BBM multimedia. Pendekatan kuantitatif digunakan dalam kajian ini dengan menggunakan soal selidik sebagai instrumen kajian. Pemilihan responden menggunakan teknik pensampelan rawak mudah yang melibatkan seramai 500 orang pelajar Tingkatan Enam yang mengambil subjek Geografi di beberapa buah sekolah yang terpilih di Malaysia. Analisis korelasi Pearson digunakan dalam kajian ini bagi meneliti hubungan antara pemboleh ubah manakala analisis regresi berganda dijalankan bagi menjelaskan pengaruh antara pemboleh ubah dalam kajian. Dapatan kajian menunjukkan pelajar mempunyai tahap yang sederhana bagi penggunaan elemen BBM multimedia, tahap tinggi bagi penerimaan pelajar terhadap reka bentuk BBM multimedia dan tahap tinggi terhadap keberkesanan penggunaan BBM multimedia. Dapatan analisis korelasi Pearson pula menunjukkan, terdapat hubungan positif yang signifikan antara keberkesanan penggunaan BBM multimedia terhadap penggunaan elemen BBM multimedia, dan penerimaan pelajar terhadap reka bentuk BBM multimedia. Selain itu, hasil analisis regresi berganda menunjukkan penerimaan elemen BBM multimedia dan penggunaan BBM multimedia memberi pengaruh terhadap keberkesanan penggunaan BBM multimedia. Kesimpulannya, kajian ini menunjukkan bahawa keberkesanan pembelajaran geografi terhadap pelajar dipengaruhi oleh penggunaan elemen BBM multimedia dan reka bentuk BBM multimedia yang menarik dan berkesan. Implikasi kajian ini secara tidak langsung dapat dijadikan sebagai panduan dan hala tuju kepada guru dalam merancang perubahan teknik dan strategi pengajaran dan pembelajaran Geografi yang lebih mudah, menarik dan menyeronokkan
\end{abstract}


seterusnya dapat memberi kesan terhadap peningkatan pencapaian maksimum akademik dan sikap pelajar.

Kata kunci: elemen BBM multimedia, keberkesanan penggunaan BBM Multimedia, reka bentuk BBM multimedia

\title{
The use and acceptance of multimedia teaching aids on the effectiveness of Geography learning
}

\begin{abstract}
Fully traditional teaching methods in presenting the contents of Geography subjects will complicate the understanding and affect the interest of students in the subject of Geography. On the basis of these issues, this study aims to examine the use of multimedia teaching aids (BBM) in Malaysia's Sixth Form Geography learning. The research involved three variables of study namely the use of multimedia BBM elements, student acceptance of multimedia BBM design, and the effectiveness of multimedia BBM used. Quantitative approach was used in this study using questionnaire as a research instrument. The selection of respondents used a simple random sampling technique involving 500 Form Six students who took Geography subjects at selected schools in Malaysia. Pearson correlation analysis was used in this study to examine the relationship between variables while multiple regression analysis was performed to explain the influence of variables in the study. The findings showed that students had a moderate level of use of multimedia BBM elements, high levels of student acceptance of multimedia BBM design and high levels of effectiveness of multimedia BBM used. The Pearson correlation analysis showed that there was a significant positive relationship between the effectiveness of multimedia BBM use towards multimedia BBM elements, and student acceptance of multimedia BBM design. In addition, multiple regression analysis showed that the acceptance of multimedia BBM elements and the use of multimedia BBM had an impact towards effective use of multimedia BBM. In conclusion, this study shows that the effectiveness of geographic learning on students wass influenced by the use of multimedia BBM elements and the attractive and effective design of multimedia BBM. The indirect implications of this study can serve as a guide and direction for teachers in designing simpler, interesting and fun geographic teaching and learning strategies and changes that can lead to improved academic achievement and student attitude.
\end{abstract}

Keywords: multimedia teaching aids element, efficient use of Multimedia teaching aids, multimedia teaching aids design,

\section{Pengenalan}

Penggunaaan teknologi dalam pendidikan yang semakin meluas di peringkat global menfokuskan guru dan pelajar untuk melengkapkan diri dengan pengetahuan dan kemahiran yang berkaitan dengan ruang lingkup teknologi yang memberi kesan yang besar terhadap kehidupan masa kini di Malaysia (Siti Aminah \& Fazlinda, 2018). Trend pendidikan semasa dan 
GEOGRAFIA Online ${ }^{\mathrm{TM}}$ Malaysian Journal of Society and Space 16 issue 3 (219-234)

(C) 2020, e-ISSN 2682-7727 https://doi.org/10.17576/geo-2020-1603-16

akan datang juga bakal berfokuskan kepada aplikasi teknologi internet dalam carian dan akses maklumat yang pelbagai untuk melahirkan modal insan bagi memenuhi kepakaran teknologi, tenaga kerja yang mampu berfikir secara kritis, inovatif dan kreatif menjelang tahun 2020 (Siti Fatimah \& Halim, 2010). Pengaplikasian ICT (Information and Communication Technology) bukan sahaja mendorong pelajar menjadi kreatif malah menjadikan PdP lebih menarik dan diintegrasikan mengikut kesesuaian topik yang hendak diajar bagi meningkatkan lagi kefahaman pelajar terhadap kandungan mata pelajaran yang diajarkan (Kementerian Pendidikan Malaysia, 2016).

Oleh yang demikian, Pelan Pembangunan Pendidikan Malaysia (PPPM) 2015-2025, melalui Kementerian Pendidikan Malaysia juga memfokuskan kepada keberhasilan, berbanding input, di samping menggunakan teknologi dan inovasi bagi memenuhi keperluan serta meningkatkan pengalaman pembelajaran pelajar (Kementerian Pendidikan Malaysia, 2015). Sehubungan itu, Kementerian Pendidikan Malaysia seharusnya memperkenalkan aplikasi perisian khusus untuk menyokong aktiviti pembelajaran dalam bilik darjah seperti penggunaan perisian BBM multimedia ini dapat mengintegrasikan teks atau mempersembahkan maklumat dengan bahanbahan media yang lain seperti audio, imej, grafik, animasi, klip video dan sebagainya bagi memenuhi keperluan, keinginan, dan menimbulkan motivasi serta minat pelajar (Mertler, 2014). Perkara ini tidak lari dalam pendidikan Geografi iaitu tidak mungkin mengasingkan individu dari peristiwa semasa. Hal ini kerana pendidikan Geografi sangat penting dalam membina hubungan antara hidupan dan alam, budaya manusia dan penggunaan sumber alam semula jadi, serta membantu pelajar memahami pola ruangan atau hubungan antara tumbuh-tumbuhan dan memahami zon iklim dunia (Degirmenci \& Ilter, 2017).

Jika disoroti, pendidikan Geografi yang berkesan di sesebuah negara bermula dari peringkat rendah, menengah dan seterusnya di peringkat yang lebih tinggi (Saedah \& Mohammed, 2012). Justeru, pendidikan Geografi yang berkualiti tinggi mempunyai tulang belakang yang kuat seperti pelajar yang mengambil bahagian dalam setiap aktiviti Geografi seperti membaca peta, paparan data, melibatkan persoalan tentang Geografi, sehinggalah pelajar yang dapat meguasai seseuatu kemahiran yang tidak diajarkan dalam bidang yang lain (Andi, Yarmaidi, \& Irma, 2015), serta penambahbaikan alat dan bahan pengajaran untuk membantu menangani masalah dan cabaran dalam pengajaran dan pembelajaran Geografi (Guzman et al., 2017).

Namun begitu, mata pelajaran Geografi kini di anggap membosankan sejak diletakkan sebagai mata pelajaran elektif yang menjadikan Geografi sebagai mata pelajaran yang terpinggir (Abdul Jalil, 2006). Sering terdengar rungutan daripada pelajar sekolah yang menyuarakan tentang pendidikan Geografi yang dianggap sebagai mata pelajaran yang komprehensif (Cifci, 2016), sangat sukar untuk difahami oleh pelajar dan memberi kesan terhadap minat mereka dalam mempelajari kandungan Geografi, juga menjadikan hal ini sebagai salah satu alasan atau sebab prestasi mereka dalam Geografi tidak memberangsangkan (Hamirdin, 2012). Mata pelajaran Geografi sering menjadi mata pelajaran pilihan terakhir bagi pelajar Tingkatan Enam berbanding mata pelajaran yang lain. Hal demikian kerana, mata pelajaran Geografi mengandungi unsur-unsur sains yang dinamik khususnya dalam Geografi fizikal (Fraile, Sanchez, \& Leatherman, 2019) menyebabkan pelajar mudah berasa bosan, tambahan pula peranan guru dalam suatu pembelajaran turut dapat mempengaruhi minat pelajar dalam Geografi melalui keberkesanan strategi pembelajaran dan alat bantu mengajar yang digunakan (Hanifah, Paulin, Nasir, Mohmadisa \& Yazid, 2017).

Dalam pengajaran mata pelajaran Geografi, maklumat harus disampaikan kepada pelajar dengan berkesan dan jelas, di samping maklumat Geografi ini diperoleh melalui teknologi sedia 
ada (Kocalar \& Demikaya, 2017). Tambahan pula, sekiranya ilmu Geografi ini diajar, dipersembah dan disebar luas dengan kaedah yang menarik dan diolah, maka mata pelajaran Geografi akan tetap diminati oleh pelajar (Hamirdin, 2012). Ini bermakna, guru merupakan role model untuk meningkatkan minat dan daya tahan pengetahuan pelajar terhadap mata pelajaran Geografi (Gokce, 2009).

Dalam konteks Tingkatan Enam, sukatan pelajaran Geografi bagi Sijil Tinggi Pelajaran Malaysia (STPM) bermula pada tahun 2013 menggalakkan pelajar untuk melayari internet seperti Google Earth dan penderiaan jauh bagi tujuan mengira dan mempersembahkan data transformasi desa dan bandar dalam bentuk jadual, gambar rajah dan juga peta (Majlis Peperiksaan Malaysia, 2012). Ini merupakan pendedahan kepada konsep asas sistem maklumat Geografi (GIS) (Kerski et al., 2013), selain melatih kemahiran dan mengembangkan cara pemahaman dan pengetahuan berkaitan ruang lingkup Geografi (Maude, 2010). Namun begitu, realiti yang berlaku di sekolah adalah multimedia sebagai bahan bantu mengajar ini dilihat kurang digunakan oleh guru-guru dan pelajar dalam pengajaran dan pembelajaran Geografi (Novaliendry, 2013).

Tambahan pula, terdapat segelintir guru yang bersikap tidak terbuka dalam mengimbangi arus pemodenan iaitu tidak mahu menggunakan BBM multimedia dalam proses pengajaran dan pembelajaran (Nandi, 2006). Hasil pengajaran yang baik tidak dapat dicapai melalui kaedah pengajaran tradisional sepenuhnya, kerana mata pelajaran ini mempunyai masa pengajaran yang terhad dengan isi kandungan pelajaran yang lebih banyak (Shouye, 2017). Akibatnya, pelajar menjadi terlalu pasif, seolah-olah mereka tidak hadir dalam proses pengajaran dan pembelajaran dalam bilik darjah tersebut (Rian \& Osman, 2013). Masalah-masalah ini yang telah menghalang usaha kerajaan untuk mengintegrasikan teknologi maklumat dan komunikasi dalam proses pengajaran dan pembelajaran di sekolah bagi mengikuti era lonjakan teknologi masa kini (Faizah, 2017). Justeru kajian ini adalah untuk meneliti tahap penggunaan bahan bantu multimedia hubungan dan sumbangan penggunaan dan penerimaan BBM multimedia terhadap keberkesanan pembelajaran Geografi.

\section{Penggunaan BBM Multimedia Dalam Pengajaran dan Pembelajaran Geografi}

Antara fokus utama penggunaan BBM multimedia dalam PdPc Geografi adalah untuk menjadikan mata pelajaran Geografi sebagai living subject, tidak susah dan menyeronokkan, serta mampu mengekalkan dan mengembangkan pengetahuan juga kemahiran pelajar (Hamirdin, 2012). Penulisan Baglama et al., (2018) menyatakan bahawa penggunaan elemen animasi dalam multimedia sebagai bahan bantu mengajar Geografi, akan menjadikan mata pelajaran ini lebih menyeronokkan kerana ciri-ciri pembelajaran animasi adalah seperti berikut;

i. Pelajar mengikuti pembelajaran secara visual.

ii. Terdapat banyak jenis permainan animasi pendidikan dan animasi video yang berkaitan dengan tajuk yang diajarkan.

iii. Untuk setiap kandungan, pelajar boleh menawarkan pelbagai animasi dengan menggabungkan pelbagai jenis animasi dengan kaedah pembelajaran yang berbeza.

iv. Pelajar dapat bermain atau menonton animasi dengan gembira dan apabila selesai, mereka dapat menyedari bahawa mereka telah belajar sesuatu daripadanya. 
GEOGRAFIA Online ${ }^{\mathrm{TM}}$ Malaysian Journal of Society and Space 16 issue 3 (219-234)

(c) 2020, e-ISSN 2682-7727 https://doi.org/10.17576/geo-2020-1603-16

Selain itu, Geografi adalah disiplin yang menarik kerana melibatkan penyelidikan berkaitan tempat dan ruang. Oleh itu, filem adalah bahan multimedia yang penting dan bermakna dalam pengajaran geografi, terutamanya filem animasi dalam menghantar maklumat berkaitan tempat dan ruang untuk menjadikan pembelajaran Geografi lebih hidup (Kenna \& Waters, 2017). Kesimpulannya penggunaan BBM multimedia adalah penting untuk mewujudkan persekitaran pembelajaran yang tidak membosankan, di samping menguji daya fikir pelajar menjadi lebih kreatif dan inovatif, memudahkan pembelajaran berkesan, menjimatkan masa dan dapat mengasah bakat dan kemahiran pelajar ke peringkat yang lebih tinggi.

\section{Penerimaan Pelajar Terhadap Reka Bentuk BBM Multimedia}

Keberkesanan sesuatu BBM multimedia, adalah bergantung kepada penerimaan pelajar terhadap reka bentuk BBM multimedia yang dipersembahkan. Hal ini disokong dengan kajian Cordova, Zarmeno dan Mejia (2015) yang menyatakan beberapa aspek yang mempengaruhi penerimaan multimedia tersebut adalah kefahaman, perspektif terknologi pendidikan, kepercayaan dan keperluan terhadap BBM multimedia dan prestasi akademik pelajar. Maklumat yang disampaikan melalui kepelbagaian strategi persembahan multimedia seperti imej, teks, dan narasi sangat mengutamakan pemilihan maklumat yang penting dan bersesuaian dengan pelajar agar dapat memberi kefahaman yang lebih jelas terhadap proses pembelajaran (Ozsvald, 2010).

Kajian Garcia, Rigo dan Jimenez (2017), menjelaskan bahawa reka bentuk suatu multimedia dalam pembelajaran adalah sangat penting, membolehkan seseorang untuk belajar dengan lebih mendalam jika suatu media tersebut dibentangkan dengan kepelbagaian elemen multimedia, berbanding pengajaran tradisional menggunakan format teks dan imej pegun semata-mata (Cubrilo, Crevenkolic, Obadovic \& Segedinac, 2014). Kesimpulannya, penerimaan pelajar terhadap reka bentuk BBM multimedia mampu membantu dalam memudahkan pemahaman terhadap topik yang diajarkan dan menjadi faktor penarik, minat dan motivasi pelajar terhadap mata pelajaran yang diajarkan dalam kelas.

\section{Keberkesanan Penggunaan BBM Multimedia}

Keberkesanan adalah keupayaan atau pencapaian yang diperoleh hasil daripada penggunaan kaedah pengajaran dan pembelajaran yang menggunakan multimedia dalam mata pelajaran Geografi, berbanding pencapaian yang diperolehi daripada penggunaan kaedah secara tradisional (Ghazali, 2013). Sebahagian pelajar akan belajar dengan lebih berkesan dengan cara melihat. Oleh itu, gambar landskap merupakan salah satu contoh sumber pengajaran Geografi yang dapat memudahkan interaksi pelajar dengan unsur-unsur landskap, di samping membolehkan pembelajaran teori yang lebih berkesan (Fraile et al., 2019). Manakala, pelajar yang lain belajar dengan lebih baik melalui pendengaran dan ada pula mendapat keberkesanan pelajaran secara optimum melalui penggabungan beberapa modaliti deria penglihatan, pendengaran dan pengalaman. Lagi banyak penglibatan modaliti deria maka lebih berkesanlah pengajaran dan pembelajaran tersebut.

Penilaian terhadap keberkesanan penggunaan BBM multimedia dalam pengajaran dan pembelajaran Geografi harus dilihat dari aspek akademik dan juga sikap pelajar, demikian kerana pendidikan Geografi itu sendiri menyokong pelajar untuk memperoleh pengetahuan, kemahiran, sikap dan nilai yang diperlukan untuk membentuk masa depan yang mampan (Feng et al., 2018). Hal demikian selaras dengan kajian yang dilakukan Cifci (2016) serta Ilhan dan 
GEOGRAFIA Online ${ }^{\mathrm{TM}}$ Malaysian Journal of Society and Space 16 issue 3 (219-234)

(C) 2020, e-ISSN 2682-7727 https://doi.org/10.17576/geo-2020-1603-16

Oruç (2016) yang mendapati bahawa penggunaan multimedia sebagai bahan bantu dalam pembelajaran Geografi mampu meningkatkan pencapaian dan akademik pelajar. Selain itu, penggunaan BBM multimedia mempunyai keupayaan untuk membebaskan pelajar dan guru dari tugas biasa supaya mereka dapat memberi tumpuan kepada aktiviti yang menggalakkan kerjasama yang lebih baik, kajian mendalam, kemahiran berfikir kritis dan memudahkan pembinaan pengetahuan dalam proses pembelajaran yang berpusatkan pelajar (Fathia, Ajlan \& Mohamad, 2016; Park \& Gentry, 2017). Sebagai contoh, alat peta animasi dan interaktif memberikan kemudahan kepada pelajar untuk mengakses pelbagai lapisan data dan beberapa alat pemetaan yang merangkumi kedua-dua ciri manusia dan fizikal, disamping meningkatkan kebolehan, minat dan penguasaan kemahiran peta dalam pengajaran dan pembelajaran Geografi (Cennamo, Ross \& Ertmer, 2014; Habibah, Arumugam, \& Teoh, 2004). Secara tidak langsung, ini akan meningkatkan emosi positif (motivasi, kepuasan, persepsi terhadap bahan), membangunkan pengalaman pembelajaran, dan seterusnya memberi kesan positif terhadap sikap pelajar (Eunjoon, Plass, Hayward \& Homer, 2012; Keller, 2016).

\section{Metod}

Kajian ini merupakan kajian kuantitatif yang menggunakan reka bentuk kajian tinjauan. Kajian ini dijalankan di seluruh Malaysia. Oleh itu, populasi bagi kajian ini adalah pelajar-pelajar Tingkatan Enam di sekolah-sekolah menengah di seluruh Malaysia. Populasi bagi pelajar Tingkatan Enam di seluruh Malaysia dianggarkan seramai 43,000 orang. Justeru, sampel bagi kajian tinjauan dianggarkan seramai 350 hingga 500 orang dikatakan sudah mencukupi (Krejcie \& Morgan, 1970). Bilangan sampel yang ditetapkan dalam kajian ini adalah 500 orang dengan ciri sampel adalah mereka yang mengambil mata pelajaran Geografi untuk peperiksaan. Teknik pensampelan rawak mudah telah digunakan bagi mendapatkan 500 sampel kajian seluruh Malaysia. Pensampelan rawak dikatakan sebagai salah satu strategi pensampelan yang terbaik dan mudah digunakan dalam suatu kajian (McCarroll, 2017; Rogerson, 2015).

Kajian ini merupakan kajian tinjauan yang menggunakan instrumen borang soal selidik. Instrumen soal selidik dipilih kerana membantu mendapatkan maklumat dengan cara cepat, mudah, murah dan cekap daripada sampel yang lebih besar, disamping dapat membantu dalam menghasilkan data mengenai tingkah laku, sikap, kepercayaan, pendapat dan pengetahuan responden (Etikan \& Bala, 2017; McLafferty, 2010; Visser, Krosnick, Lavrakas \& Kim, 2014). Walau bagaimanapun, pengedaran borang soal selidik dilakukan secara atas talian dengan menggunakan perisian google form. Hal demikian kerana, penyelidikan dalam talian mewakili salah satu perkembangan terbaru dalam kaedah tinjauan sepanjang dekad yang lalu, dan pelbagai jenis koleksi penyelidikan yang ada pada hari ini mungkin tidak dapat diterima sebelum ini tanpa bantuan media digital (Hooker \& Zuniga, 2017). Tinjauan dalam talian yang berasaskan Web sangat popular digunakan oleh penyelidik masa kini, dengan hanya menggunakan pautan yang tersedia untuk mencapai jumlah responden yang banyak (Jansen, Corley, \& Jansen, 2007) dengan cepat, mudah, murah dan berkesan serta sesuai untuk semua penyelidikan dalam semua jenis tinjauan (Raja, 2018).

Soal selidik bagi kajian ini terbahagi kepada empat bahagian iaitu Bahagian A (latar belakang responden), Bahagian $\mathrm{B}$ (penggunaan elemen BBM multimedia), Bahagian $\mathrm{C}$ (penerimaan pelajar terhadap reka bentuk BBM multimedia), dan Bahagian D (keberkesanan terhadap penggunaan BBM multimedia) (Jadual 1). Item bahagian B, diukur dalam bentuk Skala Likert 5 
mata iaitu 1 (Tidak Pernah), 2 (Hampir Tidak Pernah), 3 (Kadang-kadang), 4 (Hampir Setiap Masa), dan 5 (Setiap Masa). Manakalah kesemua item bahagian C dan D, diukur menggunakan Skala Likert 5 mata iaitu 1 (Sangat Tidak Setuju), 2 (Tidak Setuju), 3 (Kurang Setuju), 4 (Setuju) dan 5 (Sangat Setuju). Item-item yang diguna pakai untuk kajian turut disemak oleh pakar dalam bidang ini untuk memastikan item dan bahasa yang digunakan adalah sesuai dan tepat. Hasil semakan nilai kebolehpercayaan (Alpha Cronbach) bagi kesemua item dalam kajian rintis adalah melebihi 0.7 (Jadual 2). Nilai 7.0 atau lebih tinggi ditafsirkan sebagai konsisten dalaman yang boleh diterima (Adams \& Lawrence, 2015).

Jadual 1. Bilangan dan sumber item setiap pemboleh ubah

\begin{tabular}{|c|c|c|c|}
\hline Bah. & Pemboleh ubah & Bil Item & Sumber \\
\hline A & Latar belakang & $1-5$ & Dibina sendiri \\
\hline B & $\begin{array}{l}\text { Penggunaan elemen BBM } \\
\text { multimedia }\end{array}$ & $1-13$ & Dipetik dan diubahsuai daripada Sukhendu (2018). \\
\hline $\mathrm{C}$ & $\begin{array}{l}\text { Penerimaan pelajar terhadap reka } \\
\text { bentuk BBM multimedia }\end{array}$ & $1-15$ & $\begin{array}{l}\text { Dipetik dan diubah suai dari Ghazali, (2013), } \\
\text { Mastura (2014), Md. Syahrizad (2016), Siti } \\
\text { Rosminah (2016) dan Thamarana (2017) }\end{array}$ \\
\hline $\mathrm{D}$ & $\begin{array}{l}\text { Keberkesanan penggunaan BBM } \\
\text { multimedia }\end{array}$ & $1-50$ & $\begin{array}{l}\text { Dipetik dan diubah suai dari Ghazali, (2013), } \\
\text { Mastura (2014), Md. Syahrizad (2016), Nurul } \\
\text { Huda (2016), Siti Rosminah (2016) dan } \\
\text { Thamarana (2017) }\end{array}$ \\
\hline
\end{tabular}

Jadual 2. Nilai Cronbach's Alpha bagi setiap pemboleh ubah dalam soal selidik bagi kajian rintis

\begin{tabular}{lcc}
\hline Pemboleh ubah & Bil. Item & Cronbach's Alpha \\
\hline Penggunaan elemen BBM multimedia & 13 & 0.829 \\
Penerimaan terhadap reka bentuk BBM multimedia & 15 & 0.943 \\
yang digunakan & & \\
Aspek pemahaman & 10 & 0.893 \\
Aspek pengetahuan & 10 & 0.945 \\
Aspek kemahiran & 10 & 0.912 \\
Aspek motivasi & 10 & 0.945 \\
Aspek minat & 10 & 0.934 \\
\hline
\end{tabular}

Tiga fokus utama perbincangan artikel ini iaitu meneliti tahap penggunaan elemen BBM multimedia, penerimaaan reka bentuk BBM multimedia yang digunakan dan keberkesanan penggunaan BBM multimedia. Selain itu, kajian ini turut menganalisis hubungan antara penggunaan elemen BBM multimedia dan penerimaan pelajar terhadap reka bentuk BBM multimedia dengan keberkesanan penggunaan BBM multimedia, serta meneliti pengaruh serta sumbangan pemboleh ubah bebas yang menyumbang kepada keberkesanan penggunaan BBM multimedia. Bagi tujuan meneliti hubungan setiap pemboleh ubah, analisis korelasi Pearson akan digunakan dalam kajian ini yang secara langsung dapat meneliti, saiz kesan (iaitu sama ada korelasi tersebut adalah positif atau negatif). Perhubungan linear disukat dengan koefisien korelasi Pearson (r) iaitu pada aras $p<0.05$. Pekali korelasi mengandungi dua unsur iaitu nilai pekali dan tanda pekali. Pekali korelasi (r) mempunyai nilai di antara -1 hingga $1(-1<\mathrm{r}<1)$ (Cohen, Manion \& Morrison, 2007). 


\section{Dapatan Kajian Dan Perbincangan}

Bilangan keseluruhan responden dalam kajian adalah melibatkan seramai 500 orang pelajar Tingkatan Enam yang mengambil mata pelajaran Geografi di seluruh Malaysia. Daripada jumlah tersebut, pelajar perempuan adalah seramai 355 orang (71\%), manakala selebihnya adalah pelajar lelaki seramai 145 orang (29\%). Taburan kekerapan lokasi tempat tinggal responden pelajar yang berada di luar bandar adalah lebih ramai iaitu sebanyak 291 orang (58.2\%) berbanding yang tinggal di bandar iaitu 209 orang (41.8\%).

Seterusnya adalah bagi kategori negeri menunjukkan bahawa majoriti responden adalah daripada negeri Sabah seramai 142 orang (28.4\%), seterusnya adalah negeri Kelantan seramai 83 (16.6\%), Sarawak seramai 59 orang (11.8\%), Perak seramai 39 orang (7.8\%), Johor seramai 37 orang (7.4\%), Terengganu seramai 36 orang (7.2\%), Selangor seramai 34 orang (6.8\%), Pulau Pinang seramai 17 orang (3.4\%), Negeri Sembilan seramai 13 orang (2.6\%), Perlis seramai 5 orang $(1.0 \%)$, dan Kedah seramai 4 orang $(0.8 \%)$ (Jadual 3).

Jadual 3. Taburan kekerapan latar belakang responden

\begin{tabular}{llcc}
\hline Latar Belakang Responden & & Kekerapan & Peratus (\%) \\
\hline Jantina & Lelaki & 145 & 29.0 \\
& Perempuan & 355 & 71.0 \\
& Jumlah & $\mathbf{5 0 0}$ & $\mathbf{1 0 0}$ \\
Lokasi Tempat Tinggal & & \\
& Bandar & 209 & 41.8 \\
& Luar Bandar & 291 & 58.2 \\
& Jumlah & $\mathbf{5 0 0}$ & $\mathbf{1 0 0}$ \\
Negeri & & & \\
& Sabah & 142 & 28.4 \\
& Kelantan & 83 & 16.6 \\
& Sarawak & 59 & 11.8 \\
& Perak & 39 & 7.8 \\
& Johor & 37 & 7.4 \\
& Terengganu & 36 & 7.2 \\
& Selangor & 34 & 6.8 \\
& Pahang & 31 & 6.2 \\
& Pulau Pinang & 17 & 3.4 \\
& Negeri Sembilan & 13 & 2.6 \\
& Perlis & 5 & 1.0 \\
& Kedah & 4 & 0.8 \\
& Jumlah & $\mathbf{5 0 0}$ & $\mathbf{1 0 0}$ \\
\hline
\end{tabular}

a. Tahap penggunaan elemen BBM multimedia, penerimaaan reka bentuk BBM multimedia yang digunakan dan keberkesanan penggunaan BBM multimedia

Hasil kajian berkaitan tahap ini telah dikumpulkan dalam Jadual 4. Hasil dapatan menunjukkan secara keseluruhan tahap penggunaan elemen BBM multimedia dalam pengajaran dan pembelajaran Geografi, masih pada tahap sederhana $(\mathrm{M}=3.22$ dan $\mathrm{SP}=0.62)$, seramai 316 orang (63.2\%) adalah pada tahap penggunaan yang sederhana, diikuti seramai 135 orang (27.0\%) adalah pada tahap penggunaan yang tinggi, manakala seramai 49 orang (9.8\%) adalah pada tahap penggunaan yang rendah. Hal demikian selari dengan hasil kajian Abdul Jalil (2006), iaitu pelajar mengatakan mereka tidak gemar dengan mata pelajaran Geografi kerana guru Geografi 
GEOGRAFIA Online ${ }^{\mathrm{TM}}$ Malaysian Journal of Society and Space 16 issue 3 (219-234)

(C) 2020, e-ISSN 2682-7727 https://doi.org/10.17576/geo-2020-1603-16

tersebut hanya menggunakan kaedah pengajaran berbentuk "chalk and talk" dan tidak menggunakan kaedah yang dapat menarik perhatian mereka. Disamping itu, secara keseluruhan penerimaan pelajar terhadap reka bentuk BBM multimedia yang digunakan adalah pada tahap yang tinggi $(\mathrm{M}=4.11$ dan $\mathrm{SP}=0.58)$. Seramai 414 orang $(82.8 \%)$ berada pada tahap penerimaan yang tinggi terhadap reka bentuk BBM multimedia yang digunakan, manakala seramai 82 orang (16.4\%) pada tahap sederhana dan hanya empat orang $(0.8 \%)$ berada pada tahap penerimaan yang rendah. Hal ini selaras dengan kajian Eunjoon et al. (2012), iaitu penggunaan BBM multimedia mampu mendorong emosi positif (seronok dan gembira) dalam meningkatkan motivasi dan kepuasan terhadap pelajar melalui reka bentuk BBM mulmedia yang digunakan seperti warna, bentuk dan bunyi demi mengukuhkan kefahaman dan meningkatkan prestasi lebih tinggi.

Keputusan analisis secara keseluruhan bagi tahap keberkesanan penggunaan BBM Multimedia dalam pengajaran dan pembelajaran Geografi Tingkatan Enam adalah pada tahap tinggi $(\mathrm{M}=3.89$ dan $\mathrm{SP}=0.50)$ iaitu seramai 358 orang $(71.6 \%)$ keberkesanan pada tahap yang tinggi, seramai 137 orang $(27.4 \%)$ keberkesanan pada tahap sederhana, dan seramai lima orang $(1.0 \%)$ berada pada tahap rendah. Hal ini selari dengan kenyataan daripada Mohd Johdi dan Ariegusrini (2009), bahawa penggunaan BBM multimedia dalam pendidikan di Malaysia merupakan salah satu usaha yang mampu meningkatkan pengetahuan, kemahiran dan minat pelajar. Disamping itu juga, keberkesanan terhadap akademik pelajar secara keseluruhannya berada pada tahap tinggi $(\mathrm{M}=3.79$ dan $\mathrm{SP}=0.52)$. Seramai 308 orang $(61.6 \%)$ pelajar menyatakan keberkesanan terhadap akademik adalah pada tahap tinggi, 186 orang (37.2\%) keberkesanan terhadap akademik pada tahap sederhana, dan enam orang (1.2\%) menyatakan keberkesanan terhadap akademik pada tahap rendah.

Keberkesanan penggunaan BBM multimedia terhadap akademik pelajar juga diukur berdasarkan tiga sub pemboleh ubah iaitu dari pemahaman, pengetahuan dan kemahiran. Analisis keberkesanan akademik dari aspek pemahaman pelajar berada pada tahap tinggi $(\mathrm{M}=3.90$ dan $\mathrm{SP}=0.52)$ iaitu seramai 345 orang $(69.0 \%)$ mempunyai keberkesanan terhadap pemahaman yang tinggi, 151 orang $(30.2 \%)$ berada pada sederhana, dan hanya empat orang $(0.8 \%)$ mempunyai pemahaman pada tahap rendah. Hal ini selaras dengan kajian yang dilakukan Cubrilo et al. (2014), memberi kesimpulan umum bahawa terdapat kesan positif yang menunjukkan peningkatan ketara dan kualiti pengetahuan pelajar yang semakin berkembang selepas menggunakan BBM multimedia. Seterusnya adalah dari aspek pengetahuan, keberkesanan terhadap pengetahuan pelajar secara keseluruhan berada pada tahap tinggi $(\mathrm{M}=3.77$ dan $\mathrm{SP}=0.59)$ iaitu seramai 308 orang $(61.6 \%)$ mengatakan keberkesanan terhadap pengetahuan adalah tinggi, di ikuti seramai 184 orang (36.8\%) mengatakan keberkesanan terhadap pengetahuan adalah pada tahap sederhana, manakala seramai lapan orang (1.6\%) mengatakan keberkesanan terhadap pengetahuan mereka adalah pada tahap rendah. Hal demikian kerana, penggunaan multimedia dapat meningkatkan kemampuan pelajar dalam memahami suatu konsep yang abstrak dengan lebih mudah (Cubrilo et al., 2014). Bagi keberkesanan terhadap kemahiran pelajar secara keseluruhan berada pada tahap tinggi (M=3.69 dan $\mathrm{SP}=0.61)$, seramai 279 orang $(55.8 \%)$ mempunyai kesan terhadap kemahiran mereka pada tahap tinggi, 203 orang $(40.6 \%)$ kesan terhadap kemahiran pada tahap sederhana dan seramai 18 orang $(3.6 \%)$ pada tahap yang rendah.

Keberkesanan penggunaan BBM multimedia juga dapat dilihat dengan perubahan sikap pelajar yang cenderung tertarik pada proses pengajaran dan pembelajaran Geografi. Hasil analisis membuktikan bahawa secara keseluruhan keberkesanan terhadap sikap pelajar berada pada tahap tinggi $(\mathrm{M}=4.04$ dan $\mathrm{SP}=0.56)$. Majoriti pelajar iaitu seramai 402 orang $(80.4 \%)$ mempunyai keberkesanan terhadap sikap mereka pada tahap tinggi, manakala 93 orang (18.6\%) 
pada tahap sederhana dan hanya lima orang (1.0\%) pada tahap rendah. Dua sub pemboleh ubah diukur dibawah keberkesanan terhadap sikap pelajar iaitu dari aspek motivasi dan aspek minat.

Jadual 4. Tahap Penggunaan Elemen BBM Multimedia, Penerimaan Reka Bentuk BBM Multimedia, dan Keberkesanan BBM Multimedia

\begin{tabular}{|c|c|c|c|c|c|c|c|c|c|}
\hline \multirow[t]{2}{*}{ Pemboleh ubah } & \multicolumn{2}{|c|}{$\begin{array}{l}\text { Tahap } \\
\text { Rendah }\end{array}$} & \multicolumn{2}{|c|}{$\begin{array}{c}\text { Tahap } \\
\text { Sederhana }\end{array}$} & \multicolumn{2}{|c|}{$\begin{array}{l}\text { Tahap } \\
\text { Tinggi }\end{array}$} & \multirow{2}{*}{ Min } & \multirow[t]{2}{*}{ SP } & \multirow[t]{2}{*}{$\begin{array}{l}\text { Tahap } \\
\text { Purata }\end{array}$} \\
\hline & $\mathbf{N}$ & $\%$ & $\mathbf{N}$ & $\%$ & $\mathbf{N}$ & $\%$ & & & \\
\hline $\begin{array}{l}\text { Penggunaan Elemen BBM } \\
\text { Multimedia }\end{array}$ & 49 & 9.8 & 316 & 63.2 & 135 & 27.0 & 3.22 & 0.62 & Sederhana \\
\hline $\begin{array}{l}\text { Penerimaan Reka Bentuk BBM } \\
\text { Multimedia }\end{array}$ & 4 & 0.8 & 82 & 16.4 & 414 & 82.8 & 4.11 & 0.58 & Tinggi \\
\hline $\begin{array}{l}\text { Keberkesanan Penggunaan } \\
\text { BBM Multimedia }\end{array}$ & 5 & 1.0 & 137 & 27.4 & 358 & 71.6 & 3.89 & 0.50 & Tinggi \\
\hline - Akademik & 6 & 1.2 & 186 & 37.2 & 308 & 61.6 & 3.79 & 0.52 & Tinggi \\
\hline Pemahaman & 4 & 0.8 & 151 & 30.2 & 345 & 69.0 & 3.90 & 0.52 & Tinggi \\
\hline Pengetahuan & 8 & 1.6 & 184 & 36.8 & 308 & 61.6 & 3.77 & 0.59 & Tinggi \\
\hline Kemahiran & 18 & 3.6 & 203 & 40.6 & 279 & 55.8 & 3.69 & 0.61 & Tinggi \\
\hline - Sikap & 5 & 1.0 & 93 & 18.6 & 402 & 80.4 & 4.04 & 0.56 & Tinggi \\
\hline Motivasi & 11 & 2.2 & 108 & 21.6 & 381 & 76.2 & 3.91 & 0.61 & Tinggi \\
\hline Minat & 1 & 0.2 & 82 & 16.4 & 417 & 83.4 & 4.16 & 0.58 & Tinggi \\
\hline
\end{tabular}

Tahap keseluruhan keberkesanan bagi aspek motivasi berada pada tahap tinggi $(\mathrm{M}=3.91$ dan $\mathrm{SP}=0.61)$ iaitu seramai 381 orang $(76.2 \%)$ mempunyai kesan terhadap motivasi mereka pada tahap tinggi, dan seramai 108 orang $(21.6 \%)$ pada tahap sederhana, di ikuti dengan hanya seramai 11 orang $(2.2 \%)$ mempunyai kesan terhadap motivasi pada tahap rendah. Kajian ini selaras dengan kajian Mohd Johdi dan Ariegusrini (2009), penggunaan BBM multimedia memberikan kesan positif terhadap pelajar kerana dapat membantu dalam menjelaskan isi pelajaran dengan berkesan, menjimatkan masa dan meningkatkan motivasi pelajar dalam belajar. Keputusan analisis bagi sub pemboleh ubah keberkesanan terhadap minat pelajar berada pada tahap tinggi $(\mathrm{M}=4.16$ dan $\mathrm{SP}=0.58)$. Seramai 417 orang $(83.4 \%)$ mengatakan keberkesanan terhadap minat mereka adalah pada tahap tinggi, manakala seramai 82 orang $(16.4 \%)$ berada pada tahap sederhana dan hanya seorang $(0.2 \%)$ mengatakan keberkesanan terhadap minat adalah pada tahap rendah. Hal demikian kerana, semakin tinggi motivasi pelajar maka semakin tinggi minat pelajar tersebut.

b. Hubungan penggunaan elemen dan penerimaan reka bentuk BBM multimedia dengan keberkesanan penggunaan BBM multimedia

Analisis korelasi digunakan untuk meneliti hubungan pemboleh ubah bebas terhadap pemboleh ubah bersandar. Hasil analisis korelasi kajian dalam Jadual 5, menunjukkan bahawa terdapat hubungan yang signifikan antara semua pemboleh ubah iaitu penggunaan elemen BBM multimedia dan penerimaan pelajar terhadap reka bentuk BBM multimedia terhadap keberkesanan penggunaan BBM multimedia terhadap pelajar dengan nilai signifikan, $p<0.01$. Penggunaan elemen BBM multimedia $(r=0.316)$ menunjukkan korelasi positif yang sederhana dengan penerimaan pelajar terhadap reka bentuk BBM multimedia. Hasil kajian ini selari dengan kajian Salimi (2018), yang mendapati bahwa pelajar perlu membangunkan kesedaran terhadap penggunaan multimedia sebagai bahan bantu pembelajaran bagi mata pelajaran Geografi agar menjadi lebih kreatif dan inovatif, agar kesannya terhadap pembelajaran Geografi akan menjadi 
lebih mudah difahami dan jelas (Soika et al., 2010)

Di samping itu, korelasi positif yang sederhana juga ditunjukkan antara penggunaan elemen BBM multimedia dan keberkesanan penggunaan BBM multimedia ( $r=0.440)$. Dengan kata lain, guru atau pelajar yang mengaplikasikan gabungan elemen multimedia sebagai bahan bantu dalam pengajaran dan pembelajaran Geografi, dapat memberi kesan terhadap peningkatan akademik (pemahaman, pengetahuan atau kemahiran) dan juga perubahan sikap pelajar (motivasi atau minat) terhadap mata pelajaran Geografi.

Pernyataan ini selaras dengan kajian Cubrilo et al. (2014), mengesahkan bahawa pengajaran menggunakan BBM multimedia akan menghasilkan peningkatan secara signifikan terhadap kualiti pengetahuan pelajar berbanding pengajaran tradisional. Manakala, korelasi positif yang kuat antara penerimaan pelajar terhadap reka bentuk BBM multimedia dengan keberkesanan penggunaan BBM multimedia $(r=0.629)$. Keadaan ini jelas menunjukkan bahawa sekiranya BBM multimedia yang digunakan dapat menarik perhatian pelajar untuk terus fokus sepanjang PdPc Geografi, maka secara langsung akan memberi kesan terhadap peningkatan pemahaman, pengetahuan, dan kemahiran pelajar, selain membantu memotivasikan dengan menjadikan pelajar lebih produktif serta dapat menikmati pembelajaran yang menyeronokkan. Pendapat ini selaras dengan kajian Ercan (2014), yang menunjukkan bahawa apabila suasana pembelajaran yang menggembirakan dapat diwujudkan, maka akan berlaku peningkatan terhadap pengetahuan dan pencapaian akademik pelajar. Hal ini bermakna, dapatan kajian jelas menunjukkan terhadap hubungan yang signifikan antara penggunaan elemen dan penerimaan reka bentuk BBM multimedia dengan keberkesanan penggunaan BBM multimedia.

Jadual 5. Analisis korelasi penggunaan elemen BBM multimedia dan penerimaan pelajar terhadap reka bentuk $\mathrm{BBM}$ multimedia dengan keberkesanan penggunaan BBM multimedia

\begin{tabular}{|c|c|c|c|c|}
\hline \multirow[t]{2}{*}{ Pemboleh ubah } & \multicolumn{2}{|c|}{$\begin{array}{l}\text { Penerimaan Reka Bentuk } \\
\text { BBM Multimedia }\end{array}$} & \multicolumn{2}{|c|}{$\begin{array}{l}\text { Keberkesanan Penggunaan } \\
\text { BBM Multimedia }\end{array}$} \\
\hline & $\mathbf{r}$ & $p$ & $\mathbf{r}$ & $p$ \\
\hline Penggunaan Elemen BBM Multimedia & $0.316^{* * *}$ & .000 & $0.440 * *$ & .000 \\
\hline Penerimaan Reka Bentuk BBM Multimedia & & & $0.629 * *$ & .000 \\
\hline
\end{tabular}

Signifikan pada paras keyakinan 0.01 (2-tailed)

c. Sumbangan pemboleh ubah bebas yang menyumbang kepada keberkesanan penggunaan BBM multimedia

Selain itu, dalam meneliti sumbangan pemboleh ubah bebas terhadap keberkesanan penggunaan BBM multimedia, analisis regresi berganda turut digunakan. Berdasarkan model persamaan regresi ini, peramal utama adalah penerimaan pelajar terhadap reka bentuk BBM multimedia yang memberi pengaruh sebanyak 39.6 peratus, menunjukkan bahawa setiap unit pertambahan nilai pada penerimaan pelajar terhadap reka bentuk BBM multimedia akan mempengaruhi pertambahan nilai keberkesanan sebanyak 0.268 unit (Jadual 6). Peramal kedua yang terpenting juga adalah penggunaan elemen BBM multimedia yang mempunyai pengaruh sebanyak 6.5 peratus terhadap keberkesanan penggunaan BBM multimedia. Hal ini bermaksud apabila penggunaan elemen BBM multimedia ini meningkat seunit, maka nilai keberkesanan penggunaan BBM multimedia juga akan bertambah sebanyak 0.544 unit. 
Hasil keseluruhan analisis menjelaskan bahawa dua pemboleh ubah peramal iaitu penerimaan pelajar terhadap reka bentuk BBM multimedia dan penggunaan elemen BBM multimedia mempunyai korelasi dan memberi kesan kepada keberkesanan penggunaan BBM multimedia. Nilai $\mathrm{R}^{2}=0.461$ menunjukkan pengaruh keseluruhan kedua-dua pemboleh ubah peramal terhadap keberkesanan penggunaan BBM multimedia iaitu sebanyak 46.1 peratus. Nilai peratus pengaruh tersebut adalah hasil 39.6 peratus daripada pengaruh penerimaan pelajar terhadap reka bentuk BBM multimedia dan 6.5 peratus daripada pengaruh penggunaan elemen BBM multimedi. Secara keseluruhan, penggunaan elemen BBM multimedia dan penerimaan reka bentuk BBM multimedia mempunyai pengaruh terhadap keberkesanan penggunaan BBM multimedia. Dapatan kajian ini selari dengan kajian Ilhan dan Oruc, (2016); Keller (2016), iaitu penggunaan multimedia secara positif memberi kesan kepada kejayaan akademik pelajar, meningkatkan motivasi dan sikap pelajar, serta membantu membangunkan pengalaman dan pengetahuan dalam pembelajaran.

Jadual 6. Pengaruh penggunaan elemen BBM multimedia dan penerimaan pelajar terhadap reka bentuk BBM multimedia, terhadap keberkesanan penggunaan BBM multimedia

\begin{tabular}{|c|c|c|c|c|c|}
\hline \multirow[b]{2}{*}{ Pemboleh ubah bebas } & \multicolumn{3}{|c|}{$\begin{array}{c}\text { Pemboleh ubah bersandar } \\
\text { Keberkesanan Penggunaan BBM Multimedia }\end{array}$} & \multirow[b]{2}{*}{$\stackrel{\text { Sig }}{P}$} & \multirow[b]{2}{*}{$\begin{array}{c}\text { Peratus } \\
\text { Sumbangar } \\
(\%)\end{array}$} \\
\hline & $\begin{array}{c}\text { Beta tak terpiawai } \\
\text { (Understandardize } \\
\text { d Coefficient) } \\
\text { B }\end{array}$ & $\begin{array}{c}\text { Beta terpiawaian } \\
\text { (Standardardized } \\
\text { Coefficient) } \\
\beta\end{array}$ & $\begin{array}{c}\text { Statistik } \\
\mathbf{t}\end{array}$ & & \\
\hline Konstan (Pemalar) & 1.257 & & 9.762 & .000 & \\
\hline $\begin{array}{l}\text { Penerimaan Pelajar } \\
\text { Terhadap Reka Bentuk } \\
\text { BBM Multimedia }\end{array}$ & 0.471 & 0.544 & 15.677 & .000 & 39.6 \\
\hline $\begin{array}{l}\text { Penggunaan Elemen BBM } \\
\text { Multimedia }\end{array}$ & 0.215 & 0.268 & 7.723 & .000 & 6.5 \\
\hline $\begin{array}{l}\mathrm{R}=0.679 \\
\mathrm{R}^{2}=0.461(46.1 \%)\end{array}$ & $\begin{array}{l}F=2 \\
\mathrm{Sig}-\end{array}$ & & & & \\
\hline
\end{tabular}

\section{Kesimpulan}

Secara keseluruhannya, hasil kajian ini menunjukkan bahawa pengaruh yang besar terhadap keberkesanan penggunaan BBM multimedia terhadap peningkatan akademik dan sikap pelajar adalah bergantung kepada penerimaan pelajar terhadap reka bentuk BBM multimedia yang digunakan disamping mengambil kira penggunaan elemen BBM multimedia yang diaplikasikan dalam PdPc Geografi. Hal ini juga menunjukkan bahawa sekiranya BBM multimedia yang digunakan dapat menarik perhatian pelajar untuk terus fokus sepanjang PdPc Geografi, maka secara tidak langsung ini akan memberi kesan terhadap peningkatan pemahaman, pengetahuan, dan kemahiran pelajar, selain membantu memotivasikan dengan menjadikan pelajar lebih produktif serta dapat menikmati pembelajaran yang menyeronokkan. Selain itu, pemantapan teknik pengajaran dan penyebaran ilmu menggunakan BBM multimedia di sekolah adalah sangat penting untuk dalam PdPc Geografi, untuk mempertingkat kemahiran teknologi dan mempelbagai inovasi serta kreativiti tanpa mengurangkan kualiti pencapaian akademik pelajar. Hal demikian kerana, perubahan teknik dan strategi pengajaran dan pembelajaran dalam BBM 
adalah merupakan salah satu langkah terpenting dalam penyampaian ilmu yang berkesan. Perubahan terhadap teknik pembelajaran sebagai seorang pelajar juga penting untuk memacu daya fikir agar dapat dipertingkatkan, selain meningkatkan pengetahuan dan pengalaman melalui pengembangan imaginasi Geografi pelajar, juga membolehkan mereka untuk berhubung dengan orang-orang di luar kawasan penempatan, serta memupuk rasa kewarganegaraan global dan tanggungjawab terhadap alam sekitar.

\section{Rujukan}

Abdul Jalil, I. (2006). Kajian kebarangkalian kausal terhadap kecenderungan pelajar memilih Geografi sebagai mata pelajaran elektif Tingkatan 4 dalam KBSM: Satu tinjauan awal. Dalam Menanggapi Keberkesanan dan Perubahan (pp. 1-20). Tanjong Malim: Universiti Pendidikan Sultan Idris.

Adams, K. A., \& Lawrence, E. K. (2015). Research methods, statistics, and applications. London: SAGE.

Andi, S., Yarmaidi, Y., \& Irma, L. N. (2015). Perbandingan hasil belajar siswa yang menggunakan multimedia pembelajaran interaktif dan media presentasi. Journal of Progressive Education, 3(1), 1-12.

Asadi, S., \& Jamali, H. (2013). Blended library and multimedia model in Geography teaching. In Fourth International Conference on E-Learning and E-Teaching (ICELET) (pp. 47-51).

Baglama, B., Yucesoy, Y., \& Yikmis, A. (2018). Using animation as a means of enhancing learning of individuals with special needs. Journal of Association for Information Communication Technology, Education and Science., 7(3), 670-677.

Cennamo, S. K., Ross, D. J., \& Ertmer, A. P. (2014). Technology integration for meaningful classroom use: A standards-based approach ( $2^{\text {nd }}$ ed.). United Kingdom: Wadsworth Cengage Learning.

Cifci, T. (2016). Effects of infographic on students achievement and attitude towards Geography lessons. Journal of Education and Learning, 5(1), 154-166.

Cohen, L., Manion, L., \& Morrison, K. (2007). Research methods in education (6 ${ }^{\text {th }}$ ed.). London: Routledge.

Cordova, M. L. G., Zarmeno, M. G. G., \& Mejia, I. A. G. (2015). Perspective on influencing aspects for students' acceptance of multimedia materials in training programs. Open Praxis, 7(1), 57-69.

Cubrilo, D. R., Crevenkolic, Z. L., Obadovic, D., \& Segedinac, M. (2014). The application of multimedia and its effects on teaching physics in secondary school. Zbornik Instituta Za Pedagoska Istrazivanja, 46(22), 339-363.

Degirmenci, Y., \& Ilter, I. (2017). An investigation into Geography teachers' use of current events in Geography classes. Universal Journal of Educational Research, 5(10), 1806-1817.

Ercan, O. (2014). The effects of multimedia learning material on students' academic achievement and attitudes towards science courses. Journal of Baltic Science Education, 13(5), 608-621.

Etikan, I., \& Bala, K. (2017). Developing questionnaire base on selection and designing. Biometrics \& Biostatistics International Journal, 5(6), 1-3.

Eunjoon, R., Plass, J., Hayward, E., \& Homer, B. (2012). Emotional design in multimedia learning. Educational Psychology, 104(2), 485-498.

Faizah, J. (2017). Bahan bantu mengajar (BBM) dalam pengajaran dan pembelajaran (P\&P) di 
Sekolah Menengah Kebangsaan (SMK) Daerah Pontian. Disertasi Master. Johor: Universiti Tun Hussein Onn Malaysia.

Fathia, L., Ajlan, S. A., \& Mohamad, A. (2016). Proposed framework between internal, external and pedagogy dimensions in adoption of interactive multimedia e-learning. Turkish Online Journal of Distance Education, 17(4), 158-174.

Feng, G., Lane, J., Stoltman, P. J., Khlebosolova, O., Hao, L., \& Weiguo, Z. (2018). Sustainable development in Geography education for middle school in China. Sustainability, 10(11), 127.

Field, A. (2016). Quantitative methods. In D. Jackson, A. McDowall, K. Davey, \& R. Whiting (Eds.), Principles of applied research methods (pp. 260-277). London: SAGE.

Fraile, J. P., Sanchez, R. E., \& Leatherman, S. B. (2019). Improving the learning processes of physical Geography through the use of landscape photograph in class. Journal of Geography in Higher Education, 43(1), 24-39.

Garcia, D. J., Rigo, E., \& Jimenez, R. (2017). Multimedia and textual reading comprehension: Multimedia as personal learning environment's enriching format. Journal of New Approaches In Educational Research, 6(1), 3-10.

Ghazali, A. H. (2013). Keberkesanan sistem pengurusan pembelajaran exelearn di dalam pembelajaran Geografi. Disertasi Master.Tanjong Malim: Universiti Pendidikan Sultan Idris.

Gokce, N. (2009). The problems of Geography education and some suggestions. Educational Sciences: Theory \& Practice, 9(2), 757-768.

Guzman, M., Olaguer, D. L., \& Novera, G. . (2017). Difficulties faced in teaching Geography lessons at public secondary schools division of Zambales, Philippines. IOSR Journal Of Humanities And Social Science, 22(9), 64-70.

Habibah, L., Arumugam, R., \& Teoh, A. N. (2004). Penggunaan multimedia interaktif dalam pembelajaran Geografi di persekolahan. Persidangan Pendidikan Geografi Kebangsaan (II), 2(2), 1-17.

Hamirdin, I. (2012). Memacu kemahiran berfikir dan penguasaan material dalam matapelajaran Geografi di sekolah-sekolah Di Malaysia. Perspektif Journal, 4(1), 59-81.

Hanafi, Y., Hasnah, T., Mokhtar, T., Sazali, A. H., Nik Azha, N. A. R., Zawawi, Z., Azman, N. (2015). Penggunaan bahan bantu mengajar dalam pengajaran murid-murid pemulihan khas.

Hanifah, M., Paulin, C. P. L., Nasir, N., Mohmadisa, H., \& Yazid, S. (2017). Pencapaian pelajar dalam mata pelajaran Geografi Sekolah Menegah di Sabah-Analisis awal. Jurnal Sains Humanika, 9(2), 1-7

Hooker, C. M., \& Zuniga, H. G. (2017). Survey methods online. In C. S. Davis \& R. F. Potter (Eds.), The International Encyclopedia of Communication Research Methods (pp. 1-6). Austria: John Wiley \& Sons, Inc.

Ilhan, G., \& Oruc, S. (2016). Effect of the use of multimedia on students' performance: A case study of social studies class. Academic Journal, 11(8), 877-882.

Jansen, K. J., Corley, K. G., \& Jansen, J. B. (2007). E-survey methodology. In Handbook of Research on Electronic Surveys and Measurements (pp. 1-8). IGI Global.

Kaya, M. T., \& Yazici, H. (2018). Self-efficacy of the social studies teachers in using the interactive whiteboards. Review of International Geographical Education Online, 8(3), 601-612.

Keller, J. (2016). Motivation, learning, and technology: Applying the ARCS-V motivation model. Participatory Educational Research (PER), 3(2), 1-13. 
GEOGRAFIA Online ${ }^{\mathrm{TM}}$ Malaysian Journal of Society and Space 16 issue 3 (219-234)

Kementerian Pendidikan Malaysia. (2015). Pelan Pembangunan Pendidikan Malaysia (PPPM) 2015-2025. Putrajaya: Kementerian Pendidikan Malaysia.

Kementerian Pendidikan Malaysia. (2016). Buku penerangan: Kurikulum Standard Sekolah Menegah (KSSM). Putrajaya: Kementerian Pendidikan Malaysia.

Kenna, J. L., \& Waters, S. (2017). Teaching geography through an animated lens. A Journal of Educational Strategies, Issues and Ideas, 90(4), 147-151.

Kerski, J. J., Demirci, A., \& Andrew, J. M. (2013). The global landscape of GIS in secondary education. Journal of Geography, 112(6), 232-247.

Kocalar, A., \& Demikaya, H. (2017). Geography teachers ' views on effective Geography teaching. Review of International Geographical Education Online, 7(3), 332-346.

Krejcie, R. V., \& Morgan, D. W. (1970). Determining sample size for research activities. Educational and Psychological Measurement, 30, 607-610.

Lomax, R. G. (2010). Structural equation modeling. In G. R. Hancock \& R. O. Mueller (Eds.), The reviewer's guide to quantitative methods in the social science. New York: Routledge.

Majlis Peperiksaan Malaysia. (2012). Sukatan Pelajaran dan Kertas Soalan Contoh. Diperoleh daripada http://portal.mpm.edu.my/documents/10156/0c2f198f-c245-4e6b-9461-70ed7e4c7cff

Martens, D. M. (2010). Research and evaluation in education and psychology: integrating diversity with quantitative, qualitative, and mixed methods. London: SAGE.

Mastura, O. (2014). Kesan penggunaan Google Earth dalam pembelajaran peta mata pelajaran Geografi. Disertasi Master. Tanjong Malim: Universiti Pendidikan Sultan Idris.

Maude, A. (2010). What does Geography contribute to the education of young Australians? Geographical Education, 23, 14-21.

McCarroll, D. (2017). Simple statistical test for Geography. Boca Raton: CRC Press.

McLafferty, S. L. (2010). Conducting questionnaire surveys. In N. Clifford, S. French, \& G. Valentine (Eds.), Key methods in geography. Chennai, India: SAGE.

Mohd Johdi, S., \& Ariegusrini, A. (2009). Transformasi pengajaran sejarah berasaskan multimedia. Transformasi Pengajaran Dan Pembelajaran Sejarah, 113-126.

Md. Syahrizad, E. (2016). Kesan pelbagai strategi multimedia instructional message untuk pembelajaran berasaskan simulasi terhadap pencapian dan bebanan kognitif. Disertasi Ph.D. Tanjong Malim: Universiti Pendidikan Sultan Idris.

Mertler, A. C. (2014). Action research: improving schools and empowering educators. United State: SAGE.

Nandi. (2006). Penggunaan multimedia interaktif dalam pembelajaran Geografi di persekolahan. GEA Jurusan Pendidikan Geografi, 6(1), 1-9.

Novaliendry, D. (2013). Aplikasi game Geografi berbasis multimedia interaktif (studi kasus siswa kelas ix SMPN RAO). Jurnal Teknologi Dan Pendidikan, 6(2), 106-118.

Nurul Huda, M. H. (2016). Persekitaran pembelajaran, kesedaran metakognisi, kemahiran penyelesaian masalah, dan pencapaian matematik pelajar sekolah menengah. Disertasi Ph.D. Kuala Lumpur: Universiti Kebangsaan Malaysia.

Ozsvald, I. (2010). The screencasting handbook. United Kigdom: TheScreencastingHandbook.com.

Park, S., \& Gentry, V. (2017). Promoting pre-service teachers' multimedia design skills through collaborative multimedia service-learning (CMSL). Journal of Service-Learning in Higher Education, 6(1), 1-14.

Raja, T. (2018). Online tools for data collection. In Education 5.0: Perspectives and Previews (pp. 129-139). Tamil Nadu: Tamil Nadu: St. Xavier's College of Education. 
Rian, V., \& Osman, K. (2013). Keberkesanan penggunaan pelbagai media pengajaran dalam meningkatkan kemahiran proses sains dalam kalangan pelajar, 3(7), 1-11.

Rogerson, P. A. (2015). Statistical methods for Geography: a student's guide (4th ed.). Chennai, India: SAGE.

Sack, C. M. L. O. (2018). Curriculum development and pedagogy for teaching web mapping. Ph.D Dissertation. Madison: The University of Wisconsin.

Saedah, S., \& Mohammed, S. I. (2012). Standard kompetensi guru Malaysia. Kuala Lumpur: Universiti Malaya.

Siti Fatimah, A., \& Halim, T. (2010). Persepsi guru terhadap penggunaan bahan bantu mengajar berasaskan teknologi multimedia dalam pengajaran j-QAF. Journal of Islamic and Arabic Education, 2(2), 53-64.

Siti Rosminah, M. D. (2016). Kesan pelbagai strategi pembelajaran aktif berbantukan visualisasi program terhadap prestasi pengaturcaraan dan efikasi-kendiri pelajar. Disertasi Ph.D. Tanjong Malim: Universiti Pendidikan Sultan Idris.

Soika, K., Reiska, P., \& Mikser, R. (2010). The importance of animation as A visual method in advertising. International Journal of Informative \& Futuristic Research, 3(10), 1-9.

Sukhendu, M. (2018). Role of Multimedia in Education. Edelweiss Applied Science and Technology, 2(1), 187-200.

Thamarana, S. (2017). Use of multimedia technologies in English language learning: a study on English teacher. International Journal of English Language Teaching, 5(6), 526-555.

Vaziri, R., \& Mohsenzadeh, M. (2012). A questionnaire-based data quality methodology. International Journal of Database Management Systems ( IJDMS ), 4(2), 55-69.

Visser, P. S., Krosnick, J. A., Lavrakas, P. J., \& Kim, N. (2014). Survey research. In H. T. Reis \& H. M. Judd (Eds.), Handbook of Reseacrh Mehtods in Social Personality Psychology (2nd ed.). United Kingdom: Cambridge University Press. 